\title{
Enzymatic activity of a novel halotolerant lipase from Haloarcula hispanica 2TK2
}

\author{
Melis Ozgen ${ }^{1}$, Azade Attar ${ }^{1 *}$, Yeliz Elalmis ${ }^{1}$, Meral Birbir ${ }^{2}$, Sevil Yucel ${ }^{1}$ \\ ${ }^{1}$ Yildiz Technical University, Faculty of Chemical and Metallurgical Engineering, Department of Bioengineering, Esenler, \\ 34210 Istanbul, Turkey \\ ${ }^{2}$ Marmara University, Faculty of Science and Letters, Department of Biology, Goztepe, 34722 Istanbul, Turkey \\ "Corresponding author: e-mail: azadeattar@hotmail.com
}

\begin{abstract}
A strain of Haloarcula hispanica isolated from Tuzkoy salt mine, Turkey exhibited extracellular lipolytic activity. Important parameters such as carbon sources and salt concentration for lipase production were investigated. Optimal conditions for the enzyme production from Haloarcula hispanica 2TK2 were determined. It was observed that the lipolytic activity of Haloarcula hispanica was stimulated by some of the carbon sources. The high lipase acitivity values were obtained in the presence of $2 \%(\mathrm{v} / \mathrm{v})$ walnut oil $(6.16 \mathrm{U} / \mathrm{ml}), 1 \%$ (v/v) fish oil $(5.07 \mathrm{U} / \mathrm{ml}), 1 \%(\mathrm{v} / \mathrm{v})$ olive oil $(4.52 \mathrm{U} / \mathrm{ml})$ and $1 \%(\mathrm{w} / \mathrm{v})$ stearic acid $(4.88 \mathrm{U} / \mathrm{ml})$ at $4 \mathrm{M} \mathrm{NaCl}$ concentration. Lipase was partially purified by ammonium sulfate precipitation and ultrafiltration. Optimal temperature and $\mathrm{pH}$ values were determined as $45^{\circ} \mathrm{C}$ and 8.0 , respectively. Lipase activity decreased with the increasing salt concentration, but $85 \%$ activity of the enzyme was maintained at $5 \mathrm{M} \mathrm{NaCl}$ concentration. The enzyme preserved $41 \%$ of its relative activity at $90^{\circ} \mathrm{C}$. The partially purified lipase maintained its activity in the presence of surfactants such as Triton X-100 and SDS. Therefore, the lipase which is an extremozyme may have potential applications especially in detergent industry.
\end{abstract}

Keywords: Haloarcula hispanica, extremely halophilic archaea, extremozyme, lipase, lipolytic activity.

\section{INTRODUCTION}

Lipases (triacylglycerol acylhydrolases, EC 3.1.1.3) belong to the hydrolase family of enzymes. They hydrolyze triacylglycerides into fatty acids and glycerol on an oil-water interface. Additionally they can catalyze esterification, interesterification, and transesterification of fatty acids ${ }^{\mathbf{1}, 2}$. Therefore, lipases can be used in various industrial processes such as pharmaceutical, detergents, cosmetic, food, textile, hide and leather industries, pulp and paper industries, biodegradation of plastics, wastewater treatment, production of optically active compounds and production of biodiesel ${ }^{1-3}$.

Industrial lipases are mainly produced from microorganisms that secrete extracellular lipase ${ }^{4}$. Microbial lipases are usually produced by submerged fermentation and their activities are influenced by the type and concentration of carbon/nitrogen sources, $\mathrm{pH}$ and temperature ${ }^{5}$. Lipases can also be obtained from extremophiles. Extremophilic organisms have drawn much scientific interest and have important biotechnological potential because of their molecular adaptation and their ability to synthesize stable and active macromolecules in extreme environmental conditions ${ }^{6}$. Industrial processes generally occur under harsh conditions such as extreme temperatures, $\mathrm{pH}$ and salt concentrations or presence of organic solvents. For instance, lipases used in detergents should have stability and high activity over a wide range of $\mathrm{pH}$ and temperature, as well as in the presence of surfactants and metal ions. The exploration of new lipases will enhance the variety of lipolytic enzymes and thus assisting the selection of appropriate biocatalysts for challenging reactions ${ }^{7}$. Therefore, lipases derived from extremophiles, offer alternative solutions to important industrial processes.

Halophilic microorganisms are extremophilic organisms that have the ability to adapt to high salt concentrations. Halophilic proteins carry out their activities without losing resolution and preserving the $3 \mathrm{D}$ conformation in extreme conditions such as high temperature, high salt concentration, the presence of organic solvents and surfactants which cause denaturation of other proteins ${ }^{8}$. Therefore, the importance of characterization studies on stable and active lipolytic enzymes in extreme saline environments are recently increasing. Haloarcula hispani$c a$ which is an archaea thrive at high salt concentration and high temperatures ${ }^{9}{ }^{10}$. Extremozymes obtained from halophilic archaea adapt to high salt concentrations and maintain their stabilities and functions in extreme environments ${ }^{11,12}$. Therefore, extremozymes are suitable for using in the processes carried out under extreme conditions ${ }^{13}$. Hence, Haloarcula hispanica used in this study may have important application potential, especially in industrial processes carried out under harsh conditions $^{14,15}$.

In the present study, an extreme halophilic archaea Haloarcula hispanica 2TK2 strain isolated from Tuzkoy Salt Mine of Turkey, was examined for its lipase activity. The parameters influencing the lipase production such as temperature and $\mathrm{pH}$ were optimized. Lipase produced by the halophilic archaea strain was partially purified. Activity of partially purified lipase in extreme conditions and its stability in different salt concentrations and resistance to surfactants were investigated. Stability of the enzyme was investigated in the presence of certain detergent ingredients, and its suitability in these conditions were examined. This study is important because of the lack of study in the literature related to the production of lipase from extremely halophilic Haloarcula hispanica 2TK2 strain. The lipase produced by this strain may have an important potential in detergent industry.

\section{MATERIAL AND METHODS}

\section{Microorganism and culture conditions}

Haloarcula hispanica 2TK2 strain was obtained from culture collection of Biology Department, Marmara Univer- 
sity. The cells were grown aerobically at $40^{\circ} \mathrm{C}$ in a Brown medium containing $25 \% \mathrm{NaCl}, 2 \% \mathrm{MgSO}_{4} \cdot 7 \mathrm{H}_{2} \mathrm{O}, 0.5 \%$ yeast extract, $0.3 \% \mathrm{C}_{6} \mathrm{H}_{5} \mathrm{Na}_{3} \mathrm{O}_{7} \cdot 2 \mathrm{H}_{2} \mathrm{O}$, and $0.2 \% \mathrm{KCl}$ $(\mathrm{w} / \mathrm{v})^{\mathbf{1 6}, 17}$. The $\mathrm{pH}$ was adjusted to 7.5 before autoclaving. Bacterial growth was monitored by measuring optical density at $600 \mathrm{~nm}$ spectrophotometrically (Scinco S-3100, Seoul, Korea). All cultures were harvested in the late stationary phase and stored at $-20^{\circ} \mathrm{C}$.

\section{Optimization of medium components}

First, different compositions of Brown media were prepared in order to investigate optimal salt concentration and carbon source (Table 1). Salt concentration and carbon source of the medium was modified to obtain the highest activity of lipase. Effect of salinity was firstly analyzed using 3,4 and $5 \mathrm{M} \mathrm{NaCl}$ in the culture medium containing $1 \%(\mathrm{v} / \mathrm{v})$ olive oil in order to find the optimum salt concentration for the production of Haloarcula hispanica 2TK2 extracellular lipase. The test medium containing $1 \%$ olive oil $(\mathrm{v} / \mathrm{v})$ and test microorganism was incubated at $120 \mathrm{rpm} 40^{\circ} \mathrm{C}$ for 60 days. The effect of carbon sources in the culture medium was investigated using several oils or fatty acid esters such as olive (Olea europaea L.) oil (1\%, v/v), sesame (Sesamum indicum $\mathrm{L}$.) oil $(1 \%, \mathrm{v} / \mathrm{v})$, marigold (Calendula officinalis L.) oil $(1 \%, \mathrm{v} / \mathrm{v})$, bitter melon (Momordica charantia L.) oil $(1 \%, \mathrm{v} / \mathrm{v})$, polyanthus (Primula polyantha $\mathrm{L}$.) oil $(1 \%$, $\mathrm{v} / \mathrm{v})$, fish oil $(1 \%, \mathrm{v} / \mathrm{v})$, walnut (Juglans regia $\mathrm{L}$.) oil $(1 \%$ $4 \%, \mathrm{v} / \mathrm{v})$, tributyrin $(1 \%, \mathrm{v} / \mathrm{v})$, stearic acid $(1 \%, \mathrm{w} / \mathrm{v})$ and oleic acid $(1 \%, \mathrm{v} / \mathrm{v})$. Then, the effect of carbon sources was examined after the optimum salt concentration for Haloarcula hispanica 2TK2 was determined. Incubation conditions of the microorganism were $4 \mathrm{M} \mathrm{NaCl}$ at $40^{\circ} \mathrm{C}$ and $\mathrm{pH} 7.5$ (Table 1).

Table 1. Investigated carbon sources in Brown media for lipase production

\begin{tabular}{|l|c|}
\hline Medium & Carbon source \\
\hline 1 & $1 \%$ Olive oil \\
\hline 2 & $1 \%$ Sesame oil \\
\hline 3 & $1 \%$ Marigold oil \\
\hline 4 & $1 \%$ Bitter melon oil \\
\hline 5 & $1 \%$ Polyanthus oil \\
\hline 6 & $1 \%$ Fish oil \\
\hline 7 & $1 \%$ Walnut oil $+1 \%$ Tributyrin \\
\hline 8 & $1 \%$ Walnut oil $+1 \%$ Oleic acid \\
\hline 9 & $1 \%$ Walnut oil $+1 \%$ Stearic acid \\
\hline 10 & $1 \%$ Walnut oil \\
\hline 11 & $2 \%$ Walnut oil \\
\hline 12 & $3 \%$ Walnut oil \\
\hline 13 & $4 \%$ Walnut oil \\
\hline
\end{tabular}

\section{Enzyme extraction and partial purification}

Lipase production was carried out by inoculating $1 \mathrm{ml}$ of fresh culture into $25 \mathrm{ml}$ of the medium in a $100 \mathrm{ml}$ flask. The test medium was incubated at $40^{\circ} \mathrm{C}$ on an orbital shaker (Lab Companion SI-300R, JeioTech, Seoul, Korea) at $120 \mathrm{rpm}$ for 30 days. The culture was centrifuged at $15000 \mathrm{rpm}$ for $10 \mathrm{~min}$ at $4^{\circ} \mathrm{C}$. Then, the cell free supernatant was precipitated using $40 \%$ ammonium sulfate. After precipitation, samples were centrifuged at $4800 \mathrm{rpm}$ for $10 \mathrm{~min}$ at $4^{\circ} \mathrm{C}$ and supernatants were collected and Amicon stirred cell (10 kDa nitrocellulose membrane, Merck Millipore, Darmstadt, Germany) was used for ultrafiltration. Partially purified enzyme solution was washed with distilled water and phosphate buffer twice. Partially purified extracellular lipase was concentrated with ultrafiltration process by decreasing the total volume from $200-250 \mathrm{ml}$ to $25-40$ $\mathrm{ml}$ and stored.

The protein content of the enzyme extract was determined by the method of Bradford and was expressed as $\mu \mathrm{g}$ of total proteins per $\mathrm{ml}$ of the crude enzyme solution.

\section{Lipase activity assay}

\section{Titrimetric method}

A volume of $0.4 \mathrm{ml}$ of enzyme extract and $0.5 \mathrm{ml}$ of olive oil were added to $2.5 \mathrm{ml}$ of phosphate buffer (100 $\mathrm{mM}, \mathrm{pH} 7.2)$ and incubated at $37^{\circ} \mathrm{C}, 200 \mathrm{rpm}$ for 30 minutes. The reaction was stopped with the addition of $2.5 \mathrm{ml}$ ether/ethanol mixture $(1: 1 \mathrm{v} / \mathrm{v})$. Obtained mixture was titrated with $0.08 \mathrm{~N} \mathrm{NaOH}$ in the presence of phenolphthalein as indicator. All experiments were performed in triplicate. Lipase activity was calculated from $\mathrm{NaOH}$ consumption. One lipase unit was defined as the enzyme amount that causes the release of $1 \mu \mathrm{mol}$ of fatty acids per minute, under the assay conditions. Enzyme activity was expressed as units per $\mathrm{ml}$ of the crude enzyme solution.

\section{Spectrophotometric method}

Lipase activity was also measured using p-nitrophenyl palmitate (pNPP) as substrate. The activity was determined by the addition of $0.4 \mathrm{ml}$ of the crude enzyme solution to $2.5 \mathrm{ml}$ of $1 \mathrm{M}$ Tris- $\mathrm{HCl}$ buffer ( $\mathrm{pH} 7.2)$ and $2.5 \mathrm{ml}$ of $1.5 \mathrm{mM}$ pNPP. The hydrolysis reaction was carried out in water-bath at $37^{\circ} \mathrm{C}$ while shaking at 150 rpm for 15 minutes. Reaction tubes were transferred to a boiling water bath and incubated for 3 minutes to stop the hydrolysis reaction. Absorbance of p-nitrophenol released from the hydrolysis reaction of pNPP was measured at $404 \mathrm{~nm}$. One unit of lipase activity is defined as the amount of enzyme which releases $1 \mu \mathrm{mol}$ of p-nitrophenol per minute under the assay conditions. Enzyme activity was expressed as units per $\mathrm{ml}$ of the crude enzyme solution.

\section{Effects of temperature, $\mathrm{pH}$ and salt concentration on lipase activity}

Optimum temperature, $\mathrm{pH}$ and salt concentration values for lipase ( $H$. hispanica 2TK2) activity were determined. Hydrolysis reaction temperatures studied were $30,40,45,50,60,70,80$ and $90^{\circ} \mathrm{C}$. Since pNPP is degraded at high temperatures lipase activity at different temperatures was determined by titrimetric method as previously described. In order to determine the optimum $\mathrm{pH}$ for lipase activity $\mathrm{pH}$ values between 4-10 in different buffer solutions (acetate buffer at $\mathrm{pH}$ 4-5.6, phosphate buffer at $\mathrm{pH} 6-8$, Tris- $\mathrm{HCl}$ buffer at $\mathrm{pH} 9$, carbonate buffer at $\mathrm{pH} 9.2$ and 10) were studied at $45^{\circ} \mathrm{C}$. Because phenolphthalein is a $\mathrm{pH}$ dependent indicator the results were obtained spectrophotometrically at $404 \mathrm{~nm}$ as described previously. Maximum lipolytic activity was also studied in different salt concentrations ranging from 1 to $5 \mathrm{M} \mathrm{NaCl}$ in phosphate buffer. The results were obtained titrimetrically. All experiments were performed in triplicate. 


\section{Effects of surfactants}

Partially purified lipase was incubated in the presence of Triton X-100 (1-70\%, v/v) or SDS $(1,2.5,5$ and $10 \%$, $\mathrm{w} / \mathrm{v})$. After incubation for $15 \mathrm{~min}$ at $45^{\circ} \mathrm{C}, 200 \mathrm{rpm}$ and $\mathrm{pH} 8.0$ the residual enzyme activity was measured using pNPP as substrate. Enzyme activity in the absence of surfactants was marked as the control. The results were given in means of relative activity. All experiments were performed in triplicate.

\section{RESULTS AND DISCUSSION}

\section{Determination of lipase activity in the culture medium}

Lipase production was induced by the presence of olive oil in the culture medium. Media containing different concentrations of $\mathrm{NaCl}(3,4,5 \mathrm{M})$ were used for bacterial growth. The highest level of activity in the culture medium was reached after 56 days of cultivation in Brown medium containing $4 \mathrm{M} \mathrm{NaCl}$ (Fig. 1). It has been known that Bacillus spp. is the most commonly used microorganism as a lipase producer. The highest lipase activity of this strain was obtained at between $48-72 \mathrm{~h}^{\mathbf{1 9 - 2 1}}$. Although the incubation period of Haloarcula hispanica 2TK2 is much longer than the other lipase producing microorganisms, the test strain is much more stable than the other lipase producers. Halophilic microorganisms have the ability to adapt to high salt concentrations by balancing the osmotic pressure of their cytoplasm. Hypersaline media leads to protein aggregation by forming electrostatic interactions between the bonds of protein, but the halophilic proteins maintain their three-dimensional structure and conserve their activities in such environments ${ }^{\mathbf{1 9}}$. Several lipolytic enzymes have been reported which are active and stable in extreme conditions such as hypersalinity ${ }^{\mathbf{2 0}, \mathbf{2 1}}$. In our study, the lipase activity has continuously increased during the incubation period and the maximum activity $(4.73 \mathrm{U} / \mathrm{ml})$ was recorded at the 56 th day in $4 \mathrm{M} \mathrm{NaCl}$. The lipase activity of the cultures containing $3 \mathrm{M}$ and $5 \mathrm{M} \mathrm{NaCl}$ were recorded as $3.85 \mathrm{U} / \mathrm{ml}$ and $4.34 \mathrm{U} / \mathrm{ml}$, respectively which are higher than the results reported by Ozcan et al. (2009) ${ }^{\mathbf{1 8}}$.

Salt concentrations above $4 \mathrm{M}$ was determined not to have a significant effect on the lipase production, furthermore has an adverse effect on the lipolytic activity and

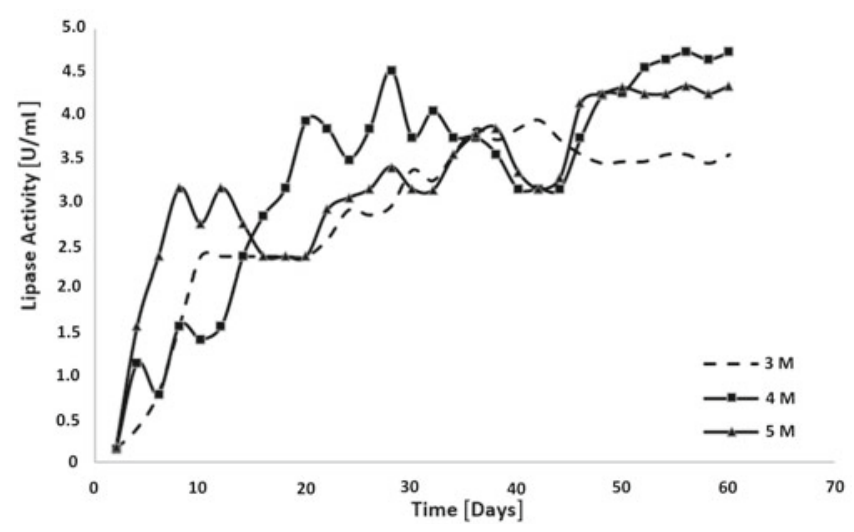

Figure 1. Lipase activity in means of salt concentration. Incubation performed in $500 \mathrm{ml}$ flasks at $100 \mathrm{rpm} 40^{\circ} \mathrm{C}$ for 60 days in presence of $1 \%$ olive oil. Results obtained by titrimetric method. All experiments performed in triplicate cell growth. Oren $(2000)^{\mathbf{1 0}}$ stated that the members of Halobacteriales need at least $1.5 \mathrm{M} \mathrm{NaCl}$ for growth and most of the strains have the optimum growth at 3.5-4.5 $\mathrm{M} \mathrm{NaCl}$ concentration. This result is also comparable to the findings of Oren ${ }^{\mathbf{1 0}}$.

\section{Effect of carbon source in the culture medium}

Lipase production was induced by the presence of different oil in the culture medium. Olive oil, sesame oil, marigold oil, bitter melon oil, polyanthus oil, fish oil and walnut oil were used as carbon source in the culture medium. All test media was analyzed for 60 days of incubation and the results were measured both by titrimetric and spectrophotometric methods. The results showed that maximum extracellular lipolytic activity decreased in the presence of oils in the following order: walnut oil $>$ fish oil $>$ olive oil $>$ sesame oil $>$ momordica oil $>$ polyanthus oil = calendula oil $($ Fig. 2$)$. The highest lipase activity has been reached in the culture media containing walnut oil and fish oil (5.43 and $5.07 \mathrm{U} / \mathrm{ml}$ ) respectively, followed by olive oil $(4.52 \mathrm{U} /$ $\mathrm{ml}$ ). Lipase from Bacillus spp. was produced by Sugihara (1991) in culture medium containing $1 \%$ olive oil ${ }^{22}$. It was reported that palm oil was the best substrate for the production of the extracellular lipase of Rhodotorula glutinis $^{\mathbf{2 3}}$. Marigold oil is a volatile oil and this oil has negative effect on cell growth. Hence, lipase production was inhibited. Likewise, polyanthus oil does not trigger the production of lipase, but it was found that the cell growth continued. In addition to the aforementioned carbon sources, tributyrin, stearic acid and oleic acid were used as carbon source to examine the effect of fatty acids on the lipase activity. All experiments were carried out at Brown media containing $4 \mathrm{M} \mathrm{NaCl}$. The lipase activities of media containing tributyrin, stearic acid and oleic acid were respectively detected as $4.88 \mathrm{U} / \mathrm{ml}$, $4.88 \mathrm{U} / \mathrm{ml}$ and $3.62 \mathrm{U} / \mathrm{ml}$. It was found that tributyrin and stearic acid have slightly increased lipase activity while oleic acid caused a decrease (Fig. 2). Our results are in agreement with the studies reported before ${ }^{24,25}$.

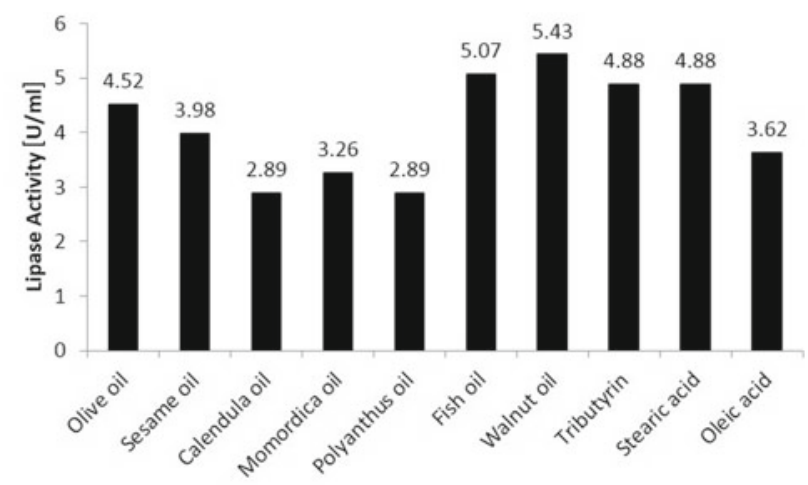

Figure 2. Lipase activity in means of carbon source. Several oils and fatty acids were used as carbon source of the growth medium in $500 \mathrm{ml}$ flasks at $100 \mathrm{rpm} 40^{\circ} \mathrm{C}$ for 60 days in presence of $4 \mathrm{M} \mathrm{NaCl}$. Results obtained by titrimetric method. All experiments performed in triplicate

Effect of the carbon source concentration in the medium

To examine the effect of different concentrations of oil on lipase activity, $4 \mathrm{M} \mathrm{NaCl}$ and $1-4 \%(\mathrm{v} / \mathrm{v})$ of walnut oil were used. The highest lipase activity was attained 
in the medium containing $2 \%$ walnut oil $(6.16 \mathrm{U} / \mathrm{ml})$, but higher concentrations of oil (3-4\% walnut oil) did not trigger lipase production (Fig. 3). Lipase activity decreased after $2 \%$ walnut oil concentration. It was reported that more than a certain amount of substrate causes an inhibition effect ${ }^{26}$. Finally, the optimum lipase production parameters were found to be $4 \mathrm{M} \mathrm{NaCl}$ and $2 \%$ walnut oil or tributyrin or stearic acid. Pérez et al. $(2011)^{27}$ reported a novel halophilic lipase produced by Marinobacter lipolyticus SM19 that exhibited high activity with short-medium length acyl chain substrates, although it also hydrolyzes long chain oils such as olive oil (1-2\%) and fish oil $(5 \%)^{27}$.

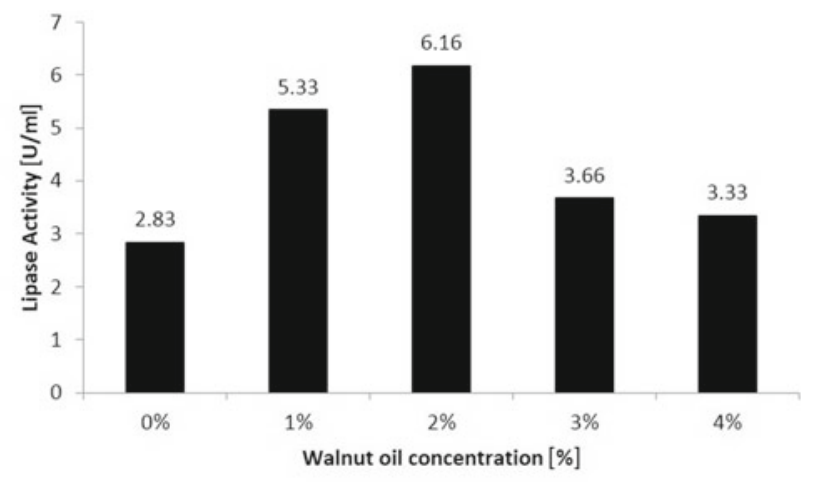

Figure 3. Lipase activity in means of carbon source concentration. Several concentrations of walnut oil were used in the growth medium in $500 \mathrm{ml}$ flasks at $100 \mathrm{rpm} 40^{\circ} \mathrm{C}$ for 60 days in presence of $4 \mathrm{M} \mathrm{NaCl}$. Results obtained by titrimetric method. All experiments performed in triplicate

\section{Partial purification of extracellular lipase}

The extracellular lipase from $H$. hispanica 2TK2 was produced and partially purified as described previously. Ammonium sulfate precipitation and ultrafiltration were applied on the supernatant for the partial purification of the lipase. Optimum saturation of ammonium sulfate precipitation was $40 \%(\mathrm{w} / \mathrm{v})$. The lipase activity was increased approximately 5 fold after partial purification (Table 2).

Table 2. Protein concentration after partial purification and lipase activity values before and after partial purification

\begin{tabular}{|c|c|c|c|c|}
\hline \multirow[b]{2}{*}{$\begin{array}{l}\text { Culture } \\
\text { media }\end{array}$} & \multicolumn{2}{|c|}{ Activity [U/ml] } & \multirow[b]{2}{*}{$\begin{array}{c}\text { Protein } \\
\text { concentration } \\
{[\mathrm{mg} / \mathrm{ml}]}\end{array}$} & \multirow[b]{2}{*}{$\begin{array}{c}\text { Specific } \\
\text { activity } \\
{[\mathrm{U} / \mathrm{mg}]}\end{array}$} \\
\hline & $\begin{array}{c}\text { before } \\
\text { partial } \\
\text { purification }\end{array}$ & $\begin{array}{c}\text { after } \\
\text { partial } \\
\text { purification }\end{array}$ & & \\
\hline 1 & 0.0127 & 0.119 & 0.379 & 0.31 \\
\hline 5 & 0.00827 & 0.061 & 0.891 & 0.19 \\
\hline 10 & 0.015 & 0.099 & 1.126 & 0.25 \\
\hline 11 & 0.015 & 0.117 & 1.227 & 0.26 \\
\hline 12 & 0.0173 & 0.175 & 1.546 & 0.32 \\
\hline
\end{tabular}

Effect of temperature, $\mathrm{pH}$ and $\mathrm{NaCl}$ concentration on enzyme activity

The partially purified lipase was incubated at various temperatures and its activity was found to be maximum at $45^{\circ} \mathrm{C}$. Lipase activity decreased at the temperature values above $45^{\circ} \mathrm{C}$, however it did not lose its activity completely even at $90^{\circ} \mathrm{C} .55,44$ and $41 \%$ of the lipase activity were preserved at 70,80 and $90^{\circ} \mathrm{C}$, respectively (Fig. 4A).

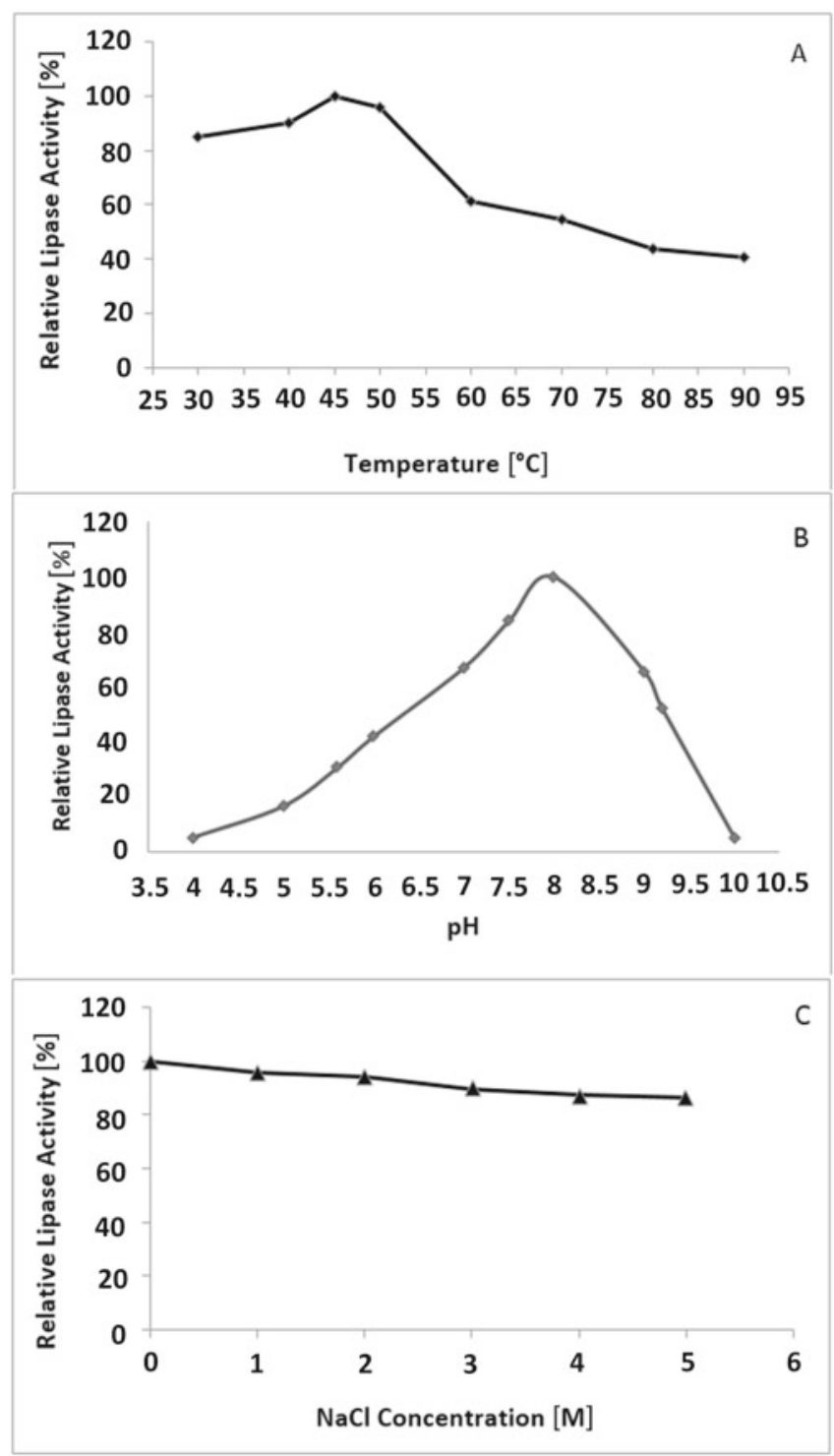

Figure 4. Effect of (A) temperature, (B) $\mathrm{pH}$ and (C) $\mathrm{NaCl}$ on 2TK2 lipase activity after $30 \mathrm{~min}$ of incubation. Relative lipase activity was measured using olive oil as substrate. Results in (A) and (C) were obtained by titrimetric method while (B) was spectrophotometric. All experiments performed in triplicate

Therefore H. hispanica 2TK2 lipase could be assumed as a thermostable lipase. Bhatnagar et al. $(2005)^{28}$ screened for lipolytic activity of Natronococcus spp. and results showed that optimum activity was attained at $40^{\circ} \mathrm{C}, 4 \mathrm{M}$ $\mathrm{NaCl}$ and $\mathrm{pH} 7.5$. However the enzyme lost all its activity at $50^{\circ} \mathrm{C}^{28}$. A thermostable lipase of the mesophilic fungus Penicillium simplicissimum was inactivated at $70^{\circ} \mathrm{C}^{29}$, but $2 \mathrm{TK} 2$ lipase tends to be more stable at high temperatures than the lipases mentioned in the literature. It was reported that an organic solvent-tolerant lipase by Haloarcula sp. G41 strain displayed optimal activity at $70^{\circ} \mathrm{C}^{30}$. Still most of the known lipases by halophilic archaea have been reported to show maximal activities between 45 and $65^{\circ} \mathrm{C}^{\mathbf{1 8 , 2 0 , 3 2}}$. Thus, the present lipase from $H$. hispanica $2 \mathrm{TK} 2$ had excellent thermostability which was observed over temperature ranging from 30 to $90^{\circ} \mathrm{C}$.

In order to determine the $\mathrm{pH}$ value in which the enzyme activity is maximum, assays were carried out in buffer solutions with different $\mathrm{pH}$ values at $45^{\circ} \mathrm{C}$, which was determined as the optimum temperature. The highest lipase activity was obtained at $\mathrm{pH} 8.0$ and the $2 \mathrm{TK} 2$ lipase 
was found to be active between pH 7.5-9.2 (Fig. 4B), retaining more than $50 \%$ of its activity. These results are similar to the results of a halotolerant Staphylococcus spp. extracellular lipase which was characterized by Daoud et al. (2013) ${ }^{\mathbf{1 9}}$. Extracellular lipase of this strain showed optimal activity at $\mathrm{pH} 8.0^{19}$. Likewise, $\mathrm{Li}$ and $\mathrm{Yu}(2014)^{30}$ reported that Haloarcula sp. G41 lipase was active at the same $\mathrm{pH}$ which is similar with our results ${ }^{30}$.

The effect of $\mathrm{NaCl}$ concentration on the 2TK2 lipase activity was investigated over a concentration range of 1-5 M. The results were obtained at $45^{\circ} \mathrm{C}$ and $\mathrm{pH}$ 8.0. It was shown that the lipase preserved nearly $85 \%$ of its activity even at high salt concentrations such as $5 \mathrm{M}$ (Fig. 4C). Results indicated that Haloarcula hispanica 2TK2 lipase was stable in a wide range of salt concentrations unlike most of the halophilic lipases ${ }^{31,32}$. The lipase preserved its activity even at low salt concentrations. This feature is interest of biotechnological and industrial processes which are performed at high salt concentrations.

\section{Effect of surfactants on enzyme stability}

The effects of Triton X-100 and SDS were investigated on the partially purified lipase activity. Addition of $1 \%$ and 5\% Triton X-100 (v/v) caused an increase of about $28 \%$ and $9 \%$ increase in lipase activity, respectively. The addition of $10 \%$ Triton X-100 (v/v) decreased lipase activity sharply (Fig. 5A). However, in the presence of
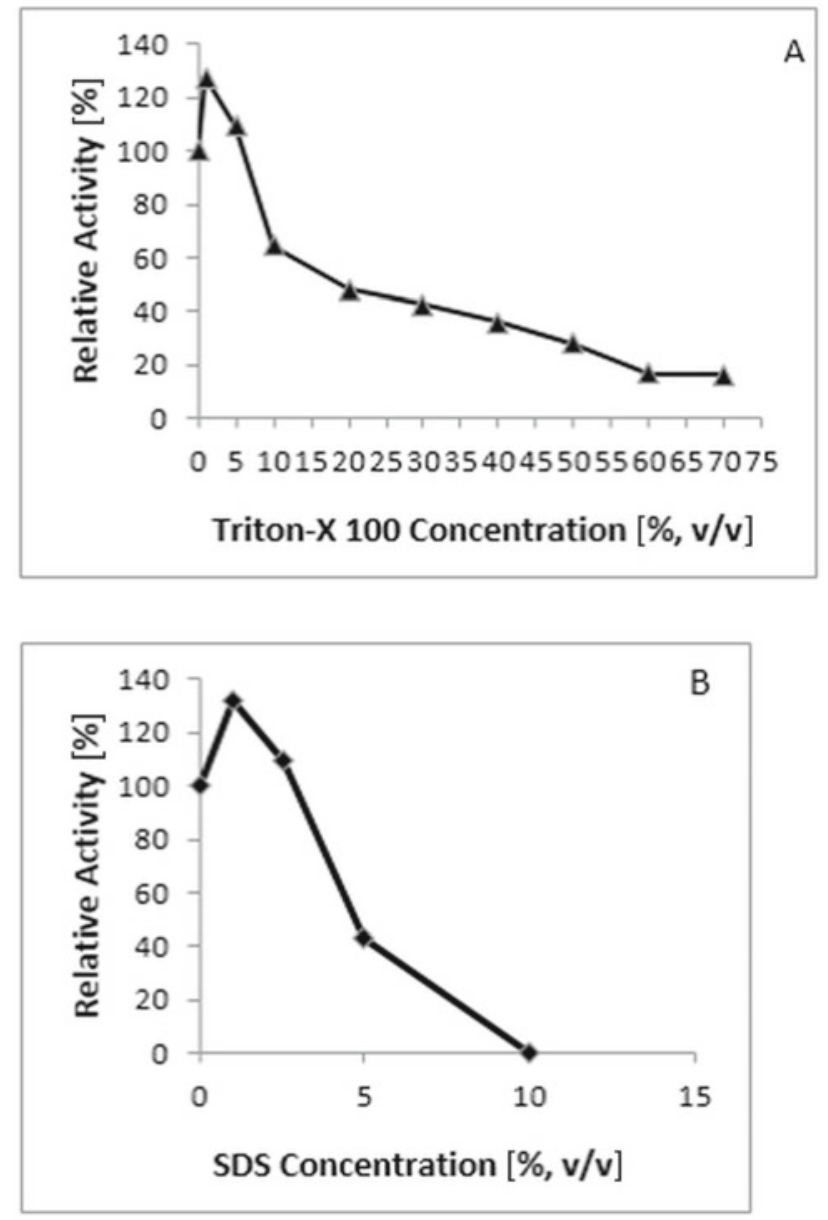

Figure 5. Effect of (A) Triton X-100 and (B) SDS on $2 \mathrm{TK} 2$ lipase activity. The enzymatic activity was measured on pNPP as substrate. All experiments performed in triplicate
$20 \%$ Triton X-100 (v/v) the enzyme preserved about $50 \%$ of its activity. Lipase activity decreased as Triton $\mathrm{X}-100$ percentage increased. In the presence of $70 \%$ Triton X-100 (v/v), which is highly concentrated, lipase preserved about $16 \%$ of its activity. It was found that $1 \%$ SDS (w/v) in the reaction environment caused an increase of $32 \%$ in the lipolytic activity while $2.5 \%$ SDS (w/v) caused $9 \%$ increase. Results showed that the lipase retained $43 \%$ of its activity in the presence of 5\% SDS $(\mathrm{w} / \mathrm{v})$ while in the presence of $10 \%$ SDS (w/v) lipolytic activity could not be observed (Fig. 5B). It has been reported that surfactants have strong inhibitory effects on lipases ${ }^{33},{ }^{34}$. Takac and Sengel $(2010)^{35}$ reported that Triton X-100 reduced lipolytic activity of Debaryomyces hansenii by $50 \%$ in the enzyme production medium containing $1.0 \%$ soybean oil ${ }^{35}$. These data showed that $H$. hispanica 2TK2 lipase is more stable than those in the literature in the presence of Triton X-100 and SDS. Thus, the present lipase from Haloarcula sp. 2TK2 can be rated among the higher thermoactive lipases.

\section{CONCLUSIONS}

Most of the industrial processes take place under harsh conditions. Hence it is very important to obtain enzymes that can maintain activity under unfavorable conditions such as extreme temperatures, salinity and $\mathrm{pH}$, or the presence of organic solvents or surfactants. Therefore, lipases derived from extremophiles, offer alternative solutions to important industrial processes. The presented enzyme has several advantages such as being resistant to high surfactant levels, active at a wide range of $\mathrm{pH}$, at high temperatures and $\mathrm{NaCl}$ concentrations.

When all results are considered, it can be said that the partially purified lipase by Haloarcula hispanica 2TK2 is thermostable and halophilic extremozyme, and has superior properties compared to other microbial lipases. It has a great biotechnological potential not only because of its thermostable properties, but also due to the low production cost. Thus it has diverse industrial applications ranging from using in detergent and paper manufacturing to the production of structured lipids, biodiesel, and biosurfactants. Also, the use of lipases in leather and hide industry to dissolve and remove fat is under rapid development and lipases are now an integrated part of leather processing in many parts of the world. Our group will focus on the purification of the enzyme in future. Determination of the molecular weight and isoelectric point of the lipase and its immobilization will be further studied.

\section{ACKNOWLEDGEMENTS}

This work was financially supported by the Scientific Research Commission of Yildiz Technical University, Project no. 2013-07-04-YL06.

\section{LITERATURE CITED}

1. Ramos, E.Z., Júnior, R.H.M., de Castro, P.F., Tardioli, P.W., Mendes, A.A., Fernandéz-Lafuente, R. \& Hirata, D.B. (2015). Production and immobilization of Geotrichum candidum lipase via physical adsorption on eco-friendly support: Characterization of the catalytic properties in hydrolysis and esterification reactions. J. Mol. Catal. B-Enzym. 118, 43-51. DOI: 10.1016/j. molcatb.2015.05.009. 
2. Maldonado, R.R., Aguiar-Oliveira, E., Pozza, E.L., Costa, F.A.A., Mazutti, M.A., Maugeri, F. \& Rodrigues, M.I. (2015). Application of yeast hydrolysate in extracellular lipase production by Geotrichum candidum in shaken flasks, stirred tank, and airlift reactors. Can. J. Chem. Eng. 93, 1524-1530. DOI: $10.1002 /$ cjce. 22260.

3. Souza, R.L., Lima, R.A., Coutinho, J.A., Soares, C.M. \& Lima, Á.S. (2015). Novel aqueous two-phase systems based on tetrahydrofuran and potassium phosphate buffer for purification of lipase. Process. Biochem. 50, 1459-1467. DOI: 10.1016/j. procbio.2015.05.015.

4. Gupta, R., Gupta, N. \& Rathi, P. (2004). Bacterial lipases: An overview of production, purification and biochemical properties. Appl. Microbiol. Biotechnol. 64, 763-781. DOI: 10.1007/ s00253-004-1568-8.

5. Beisson, F., Tiss, A., Rivière, C. \& Verger, R. (2000). Methods for lipase detection and assay: A critical review. Eur. J. Lipid. Sci. Technol. 102, 133-153. DOI: 10.1002/(SICI) 1438-9312.

6. Kushner, D.J. (1993). Growth and nutrition of halophilic bacteria; In: R. H. Vreeland and L. Hochstein (eds): The Biology of Halophilic Bacteria (pp. 87-103). Boca Raton, FL, USA: CRC Press.

7. Su, J., Zhang, F., Sun, W., Karuppiah, V., Zhang, G., Li, Z. \& Jiang, Q. (2015). A new alkaline lipase obtained from the metagenome of marine sponge Ircinia sp. World. J. Microb. Biot. 31, 1093-1102.

8. Oren, A. (2002). Cellular Origin and Life in Extreme Habitats, Halophilic Microorganisms and Their Environments (2002 ed.). NY, USA: Kluwer Academic Publishers.

9. Kushner, D.J. (1978). Life in high salt and solute concentrations: halophilic bacteria; In: Kushner D.J. (ed.) Microbial Life in Extreme Environments (pp. 317-368). London, UK: Academic Press.

10. Oren, A. (2000). Life at high salt concentrations; In: The Prokaryotes. A Handbook on the Biology of Bacteria: Ecophsiology, Isolation, Identifications, Applications (3rd ed.). NY, USA: Springer Verlag.

11. MacElroy, R.D. (1974). Some comments on the evolution of extremophiles. Biosystems 6, 74-75. DOI: Not found.

12. Eichler, J. (2001). Biotechnological uses of archaeal extremozymes. Biotechnol. Adv. 19, 261-278. DOI: 10.1016/ S0734-9750(01)00061-1.

13. Gomes, J. \& Steiner, W. (2004). The biocatalytic potential of extremophiles and extremozymes. Food Technol. Biotechnol. 42, 223-235. DOI: Not found.

14. van den Burg, B. (2003). Extremophiles as a source for novel enzymes. Curr Opin Microbiol. 6, 213-218. DOI: 10.1016/ S1369-5274(03)00060-2.

15. Emampour, M., Noghabi, K.A. \& Zahiri, H.S. (2015). Molecular cloning and biochemical characterization of a novel cold-adapted alpha-amylase with multiple extremozyme characteristics. J. Mol. Catal. B: Enzym. 111, 79-86. DOI: 10.1016/j. molcatb.2014.10.012

16. Brown, A.D. (1963). The peripheral structures of Gramnegative bacteria. IV. The cation-sensitive dissolution of the cell membrane of the halophilic bacterium Halobacterium halobium. Biochim. Biophys. Acta 75, 425-435. DOI: 10.1016/00063002(63)90630-9.

17. Attar, A., Ogan, A., Yucel, S. \& Turan, K. (2016). The potential of archaeosomes as carriers of pDNA into mammalian cells. Artif Cells Nanomed Biotechnol. 44, 710-716. DOI: 10.3109/21691401.2014.982800.

18. Ozcan, B., Ozyilmaz, G., Cokmus, C. \& Caliskan, M. (2009). Characterization of extracellular esterase and lipase activities from five halophilic archaeal strains. J. Ind. Microbiol. Biotechnol. 36, 105-110. DOI: 10.1007/s10295-008-0477-8.

19. Daoud, L., Kamoun, J., Ali, M.B., Jallouli, R., Bradai, R., Mechichi, T., Gargouri, Y. Ali, Y.B. \& Aloulou, A. (2013). Purification and biochemical characterization of a halotolerant
Staphylococcus sp. extracellular lipase. Int. J. Biol. Macromol. 57, 232-237. DOI: 10.1016/j.ijbiomac.2013.03.018.

20. Boutaiba, S., Bhatnagar, T., Hacene, H., Mitchell, D.A. \& Baratti, J.C. (2006). Preliminary characterization of a lipolytic activity from an extremely halophilic archaeon Natronococcus sp. J. Mol. Catal. B: Enzym. 41, 21-26. DOI: 10.1016/j. molcatb.2006.03.010.

21. Rohban, R., Amoozegar, M.A. \& Ventosa, A. (2009). Screening and isolation of halophilic bacteria producing extracellular hydrolyses from Howz Soltan Lake, Iran. J. Ind. Microbiol. Biotechnol. 36, 333-340. DOI: 10.1007/s10295-008-0500-0. 22. Sugihara, A., Tani, T. \& Tominaga, Y. (1991). Purification and characterization of a novel thermostable lipase from Bacillus sp. J. Biochem. 109, 211-216. DOI: Not found.

23. Sugiura, M., Oikawa, T., Hirano, K. \& Inukai, T. (1977). Purification, crystallization and properties of triacylglycerol lipase from Pseudomonas fluorescens. Biochim. Biophys. Acta 488, 353-358. DOI: 10.1016/0005-2760(77)90194-1.

24. Arpigny, J.L., Jendrossek, D. \& Jaeger, K.E. (1998). A novel heat-stable lipolytic enzyme from Sulfolobus acidocaldarius DSM 639 displaying similarity to polyhydroxyalkanoate depolymerases. FEMS Microbiol. Lett. 167, 69-73. DOI: 10.1111/j.15746968.1998.tb13209.x.

25. Kim, H.K., Jung, Y.J., Choi, W.C., Ryu, H.S., Oh, T.K. \& Lee, J.K. (2004). Sequence-based approach to finding functional lipases from microbial genome databases. FEMS Microbiol. Lett. 235, 349-355. DOI: 10.1111/j.1574-6968.2004.tb09609.x. 26. Sengel, B.S. (2007). Investigation of microbial lipase production conditions as detergent additive. Unpublished dissertation. Ankara University, Ankara, Turkey.

27. Pérez, D., Martín, S., Fernández-Lorente, G., Filice, M., Guisán, J.M., Ventosa, A. \& Mellado, E. (2011). A novel halophilic lipase, LipBL, showing high efficiency in the production of eicosapentaenoic acid (EPA). PLoS One 6(8):e23325. DOI: 10.1371/journal.pone.0023325.

28. Bhatnagar, T., Boutaiba, S., Hacene, H., Cayol, J.L., Fardeau, M.L., Ollivier, B. \& Baratti, J.C. (2005). Lipolytic activity from Halobacteria: Screening and hydrolase production. FEMS Microbiol. Lett. 248, 133-140. DOI: 10.1016/j.femsle.2005.05.044. 29. Gutarra, M.L.E., Godoy, M.G., Maugeri, F., Rodrigues, M.I., Freire, D.M.G. \& Castilho, L.R. (2009). Production of an acidic and thermostable lipase of the mesophilic fungus Penicillium simplicissimum by solid-state fermentation. Bioresour Technol. 100, 5249-5254. DOI: 10.1016/j.biortech.2008.08.050. 30. Li, X. \& Yu, H.Y. (2014). Characterization of an organic solvent-tolerant lipase from Haloarcula sp. G41 and its application for biodiesel production. Folia Microbiol. 59, 455-463. DOI: $10.1007 / \mathrm{s} 12223-014-0320-8$.

31. Muller-Santos, M., de Souza, E.M., Pedrosa, F.O., Mitchell, D.A., Longhi, S., Carriere, F., Canaan, S. \& Krieger, N. (2009). First evidence for the salt dependent folding and activity of an esterase from halophilic archae Haloarcula marismortui. Biochim. Biophys. Acta 1791, 719-729. DOI: 10.1016/j.bbalip.2009.03.006.

32. Camacho, R.M., Mateos, J.C., Gonzalez-Reynoso, O., Prado, L.A. \& Cordova, J. (2009). Production and characterization of esterase and lipase from Haloarcula marismortui. J. Ind. Microbiol. Biotechnol. 36, 901-909. DOI: 10.1007/s10295-009-0568-1. 33. Delorme, V., Dhouib, R., Canaan, S., Fotiadu, F., Carrière, F. \& Cavalier, J.F. (2011). Effects of surfactants on lipase structure, activity, and inhibition. Pharm. Res. 28, 1831-1842. DOI: 10.1007/s11095-010-0362-9.

34. Palacios, D., Busto, M.D. \& Ortega, N. (2014). Study of a new spectrophotometric end-point assay for lipase activity determination in aqueous media. LWT-Food Sci. Technol. 55, 536-542. DOI: 10.1016/j.lwt.2013.10.027.

35. Takac, S. \& Sengel, S. (2010). Extracellular lipolytic enzyme activity of a newly isolated Debaryomyces hansenii. Prep Biochem. Biotechnol. 40, 28-37. DOI: 10.1080/10826060903388820. 